MATEC Web of Conferences 10, 03002 (2014)

DOI: $10.1051 /$ matecconf/ 20141003002

(C) Owned by the authors, published by EDP Sciences, 2014

\title{
Performance Assessment of Maintenance Practices in Government Office Buildings: Case Study of Parcel E, Putrajaya
}

\author{
A.I. Awg Husaini ${ }^{1}$ and A.A. Tabassi ${ }^{2, a}$ \\ ${ }^{1,2}$ School of Housing, Building and Planning, Universiti Sains Malaysia, 11800 Penang, Malaysia
}

\begin{abstract}
Building maintenance practices must be taken into consideration by building facility managers or building owners. They involve daily operations to ensure that end users can work or live comfortably and safely. Through effective maintenance practices, the functions of the existing building facilities can be maintained and meet the needs of the building users. Maintenance practices must be effective in aspects such as planning, organization and supervision in order to maintain the building at a satisfactory level of performance all the time. A study was conducted on a Federal government office building in Parcel E, Putrajaya to determine the maintenance aspects of the management of the facility. To achieve the objectives of this study a questionnaire survey was used to obtain the required data. The outcomes indicate that the aspects of building maintenance practice and the effectiveness of the maintenance management in government office buildings can influence the satisfaction of the end user. However, some aspects of the current building maintenance practices seem to need improvements in order to enhance the building maintenance management. The recommendations of this study will help in the effective management of the facility and maintenance management practices.
\end{abstract}

\section{Introduction}

Maintenance management in the private and public sectors has been rapidly changing throughout the years. This is due to several factors such as enhancement of sophisticated technologies, globalization and economic changes [1]. There are many definitions of maintenance. A prime aim of building maintenance is to preserve a building in its initial effective state, as far as practicable, so that it serves its purpose effectively [2,3]. Maintenance can be defined as an activity that aims to optimize the availability and reliability of production equipment and to maintain its operability at an acceptable cost level [4]. It is also described as a systematic direction and control of operational processes [5]. In recent years there have been many developments of a generic nature that have had a profound impact on the manner in which estates are managed and maintained. A significant driver has been the rapid growth of facilities management, and connected with this, directly and indirectly, have been initiatives in procurement strategies, contracting out, and performance monitoring and measurement [6].

\footnotetext{
${ }^{a}$ Corresponding author: akhavan@usm.my
} 
The best way to achieve excellent maintenance is to have a maintenance management that matches as closely as possible the expected requirements of the user [7]. Although this study aims to unveil the problems that occur in the performance assessment of maintenance practices of building maintenance in some government offices and to determine the client's or user's level of satisfaction, it is also used to fulfil other objectives. Other than that, the building management has to ensure that the buildings have facilities that provide services to the people. These services include electricity, piping, lifts for high rise buildings, maintenance, and workers who handle cleaning, security and others [8]. The availability of such facilities will make the public want to keep coming to the building because they are very satisfied with the services. This can also actually increase the economy of that city. Maintenance management involves services associated with real estate management and systems. Of course, the motivations for outsourcing in any industry are driven by an ever-greater organizational pursuit to ensure cost discipline, whilst improving the quality of service and the delivery capability [9].

\section{Problem Statement}

Despite the realization of the importance of the management and maintenance of buildings and facilities, it has not been emphasized clearly and systematically, and this has resulted in over-budget costing for maintenance and remedial works [10]. Many complaints of defects in public buildings have been reported such as the collapse of the ceiling in the Parliament building in 2006, leaking pipes in Mahkamah Jalan Duta (Official Court, Jalan Duta, Kuala Lumpur) and the appearance of fungus at the Sultanah Aminah Hospital, Johor in 2007. The reported cases are described in a chronology of events starting from 2005 to 2007 (see Table 1).

Table 1. Chronology of Defects Occurrence in Government and Public Buildings

\begin{tabular}{|l|l|}
\hline \multicolumn{1}{|c|}{ DATE/YEAR } & \multicolumn{1}{c|}{ CHRONOLOGY OF DEFECTS OCCURENCE } \\
\hline April 2005 & Collapsed ceiling at Parliament Building \\
\hline *Year 2006 & Fungus infection on wall at Hospital Sultanah Aminah, Johor Bharu \\
\hline *Year 2007 & Defects at Navy Recruit Training Centre (PULAREK), Johor \\
\hline *Year 2007 & NKVE-Meru highway collapse \\
\hline *Year 2007 & Floods from 7th floor down to 2nd floor at Immigration Department Putrajaya \\
\hline *Year 2007 & Plaster ceiling collapse at Entrepreneurial Department Putrajaya \\
\hline 14 May 2007 & Collapsed ceiling at the new court complex in Jalan Duta, Kuala Lumpur \\
\hline 17 May 2007 & Collapsed ceiling at Parliament Building \\
\hline 21 May 2007 & Leaking pipes caused flooding at the new court complex in Jalan Duta, Kuala Lumpur \\
\hline 28 May 2007 & Collapsed ceiling at Hospital Sultan Abdul Halim, Sg. Petani, Kedah \\
\hline November 2007 & Fungus infection on wall at Hospital Umum Sarawak (HUS), Kuching \\
\hline November 2007 & Fungus and spores detected on wall at Hospital Temerloh (HoSHAHS) Pahang \\
\hline
\end{tabular}

These issues may have been due to inconsistent building maintenance practices. In a bid to fulfil the demands of the private and public sectors, there are many expected errors and defects that will occur during the construction and that will result in high maintenance costs. Furthermore, organizations need effective managers and employees to maintain smooth management. Organizations cannot succeed without the efforts and commitment of their personnel. In addition, poor building design has been considered as an issue in building maintenance [11]. Differences in the capacity and the facilities provided will trigger a different maintenance treatment that requires more investigation to identify whether the present maintenance system can be implemented for all building facilities [12]. Most of the government office buildings in Malaysia have their specifications for each 
type of building or space that are set out in the guidelines and rules for building plans by the Committee on Standards and Cost, Economic Planning Unit, Prime Minister's Department.

\section{Methodology}

This case study is based on a literature review, which guided the researchers with regard to the existing maintenance practices that are being observed by facility management offices, and a questionnaire survey. The questionnaire survey method was chosen because it is the most convenient method to use for all levels of participants, and many of the possible subjects move around the building during the course of their work, which makes interviewing problematic [13].

The case studies involved 14 blocks of government office buildings in Parcel E, Putrajaya and the respondents were the occupants of each block. Aside from the questionnaire survey, some observations were also made of the current condition of the buildings. The data obtained from the questionnaire survey were analysed for the research evaluation of the building maintenance practices and the systems that were applied.

Observation was also an important step in meeting the objectives of this study. This was because it led to certain conditions or behaviours that occurred in a particular environment. Observations were carried out during a visit to the selected case studies. The results were based on direct observations of the input in these case studies. In the questionnaire survey, 200 questionnaires were distributed to 14 office blocks and 140 sets were returned for analysis. These questionnaires were randomly distributed to each block with between 10 to 12 respondents in each block.

\section{Data Analysis and Findings}

The analysis of this case study was with regard to the building performance assessment maintenance practices that the management facility provides to the end users and to determine from the scores whether the users are' very dissatisfied', 'dissatisfied', 'average', 'satisfied', or 'very satisfied' with the performance delivery. The features presented consisted of an analysis on the survey findings pertaining to the satisfaction level of the building occupants. The findings were derived from 140 survey questionnaires that were returned out of the 200 questionnaires that had been distributed. The data obtained from the questionnaires were used to provide specific findings to the study and to provide recommendations in terms of a strategic implementation plan to enhance maintenance service delivery. The data analysis was performed using the Statistical Analysis Software SPSS 19.0. The mean value can be determined based on the aggregate data using the SPSS 19.0 in order to get the average value for each parameter in each building block. The building performance score is 'very dissatisfied' if the scale category is below 1.99, 'average' if the scale is near 3, and 'very satisfied' if the scale category is above 5 .

\subsection{Building performance score results for the implementation of maintenance works}

Table 2 presents a summary of the results of each building performance score based on the 16 parameters in the questionnaire. The results show that generally the performance of the sample blocks was within the 'average' to 'high' category (3.00 to 3.99). Only the users of Block 3 were dissatisfied (2.00 to 2.99) with the performance in terms of roof, ceiling, building structure, floor surface and external wall repairs. Meanwhile, Block 4 occupants were dissatisfied (2.00 to 2.99) with the performance in terms of internal wall and door repairs as the score obtained was 2.90. Overall, as shown in Table 3, the results for the building performance score in terms of the implementation of maintenance works was between 'average' to 'satisfied'. 


\subsection{Building performance score results for the delivery feature}

Table 4 presents a summary of the results for each building performance score based on the 8 parameters in the questionnaire. The results from Table 4 show that generally the performance of the blocks was in the 'average' category (3.00 to 3.99). Only Block 3 occupants showed dissatisfaction (2.00 to 2.99) over the performance in terms of the response of the maintenance officer/technician, communications with the maintenance officer, and the action taken by the officer-in-charge to manage complaints, as the score obtained was 2.80 to 2.90 . Generally, the score for the implementation of maintenance works was in the 'average' category (3.00 to 3.99). In contrast, the users in Block 3 showed a level of dissatisfaction (2.00 to 2.99) that requires the management of the building to pay more attention to this particular block to identify any chronic problems.

Table 2. Building performance score for the implementation of maintenance works for each block

\begin{tabular}{|c|c|c|c|c|}
\hline $1.00-1.99$ & $2.00-2.99$ & $3.00-3.99$ & $4.00-4.99$ & $5.00-5.99$ \\
\hline $\begin{array}{c}\text { Very } \\
\text { Dissatisfied }\end{array}$ & Dissatisfied & Average & Satisfied & Very Satisfied \\
\hline
\end{tabular}

\begin{tabular}{|c|c|c|c|c|c|c|c|c|c|c|c|c|c|c|}
\hline $\begin{array}{l}\text { Implementation of maintenance } \\
\text { works on : }\end{array}$ & 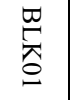 & 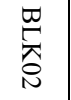 & $\underset{\stackrel{\sigma}{\widetilde{\sigma}}}{\stackrel{\varpi}{\sigma}}$ & 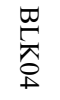 & 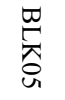 & $\frac{\square}{\stackrel{\varpi}{\overparen{\sigma}}}$ & 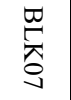 & 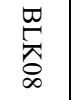 & 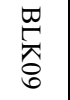 & $\underset{\stackrel{\varpi}{\widetilde{T}}}{\stackrel{\varpi}{\sigma}}$ & $\begin{array}{l}\underset{\Xi}{\widetilde{\Xi}} \\
\underset{\Xi}{二}\end{array}$ & 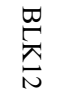 & $\underset{\omega}{\underset{\omega}{\widetilde{C}}}$ & 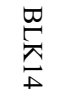 \\
\hline Roof repair & 3.55 & 3.33 & 2.70 & 3.50 & 3.27 & 3.44 & 3.00 & 3.40 & 3.00 & 3.56 & 3.27 & 3.67 & 3.60 & 3.10 \\
\hline Ceiling repair & 3.45 & 3.44 & 2.80 & 3.60 & 3.36 & 3.44 & 3.10 & 3.40 & 2.91 & 3.33 & 3.00 & 3.44 & 3.40 & 2.90 \\
\hline Building structure repair & 3.64 & 3.67 & 2.80 & 3.40 & 3.27 & 3.22 & 3.30 & 3.70 & 3.27 & 3.89 & 3.64 & 3.78 & 4.00 & 3.60 \\
\hline Floor surface repair & 3.91 & 3.44 & 2.90 & 3.20 & 3.45 & 3.44 & 3.30 & 4.30 & 3.55 & 4.33 & 4.18 & 4.00 & 4.50 & 4.10 \\
\hline External wall repair & 3.64 & 3.56 & 2.90 & 3.10 & 3.18 & 3.22 & 3.20 & 3.70 & 3.27 & 4.00 & 3.82 & 3.89 & 4.10 & 3.60 \\
\hline Internal wall repair & 3.64 & 3.67 & 3.00 & 2.90 & 3.27 & 3.11 & 3.20 & 3.80 & 3.45 & 4.00 & 4.00 & 3.78 & 4.20 & 3.80 \\
\hline Doors repair & 3.73 & 3.56 & 3.00 & 2.90 & 3.45 & 3.56 & 3.30 & 4.10 & 3.27 & 4.00 & 3.91 & 3.56 & 4.20 & 4.00 \\
\hline Windows repair & 3.55 & 3.78 & 3.20 & 3.00 & 3.36 & 3.44 & 3.10 & 3.80 & 3.64 & 3.89 & 3.91 & 3.44 & 3.90 & 3.60 \\
\hline Sanitary fittings repair & 3.36 & 3.67 & 3.00 & 3.10 & 3.36 & 3.56 & 3.50 & 3.70 & 3.73 & 3.67 & 3.55 & 3.22 & 3.70 & 3.40 \\
\hline Air-condition repair & 3.64 & 3.78 & 3.20 & 3.30 & 3.82 & 3.67 & 3.40 & 3.60 & 3.73 & 3.89 & 3.82 & 3.89 & 3.90 & 3.50 \\
\hline Lighting repair & 4.09 & 3.89 & 3.60 & 3.50 & 3.82 & 3.56 & 3.60 & 4.00 & 4.27 & 4.33 & 4.45 & 4.22 & 4.40 & 4.10 \\
\hline Electrical installation repair & 3.91 & 3.78 & 3.40 & 3.60 & 3.64 & 3.33 & 3.60 & 3.90 & 3.91 & 4.11 & 4.09 & 3.89 & 4.20 & 3.80 \\
\hline Fire fighting system check & 3.91 & 3.22 & 3.20 & 3.60 & 3.36 & 3.67 & 3.00 & 4.10 & 3.82 & 4.22 & 4.00 & 4.11 & 4.50 & 4.00 \\
\hline External building cleanse & 3.45 & 3.56 & 3.00 & 3.40 & 3.64 & 3.89 & 3.20 & 3.40 & 3.64 & 3.67 & 3.45 & 3.56 & 3.60 & 3.40 \\
\hline Internal building cleanse & 4.00 & 4.11 & 3.20 & 3.40 & 3.45 & 3.78 & 3.50 & 4.00 & 4.27 & 4.33 & 4.36 & 4.11 & 4.30 & 4.10 \\
\hline Toilet cleanse & 3.73 & 3.56 & 3.00 & 2.90 & 3.55 & 3.33 & 3.40 & 4.40 & 4.18 & 4.56 & 4.27 & 4.11 & 4.40 & 4.30 \\
\hline
\end{tabular}

Table 3. Overall building performance score for the implementation of maintenance works

\begin{tabular}{|c|c|c|c|c|c|c|c|c|c|c|c|c|c|c|}
\hline & $\begin{array}{l}\underset{\Xi}{\sigma} \\
\stackrel{\widetilde{\sigma}}{\varrho}\end{array}$ & 尝 & 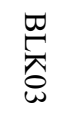 & 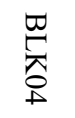 & 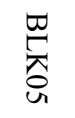 & 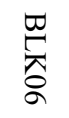 & 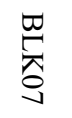 & 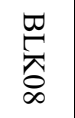 & $\begin{array}{l}\underset{D}{\mathbb{T}} \\
\stackrel{0}{8}\end{array}$ & $\begin{array}{l}\underset{巳}{\widetilde{T}} \\
\text { ○ }\end{array}$ & $\begin{array}{l}\underset{C}{\widetilde{Z}} \\
\stackrel{\Xi}{=}\end{array}$ & 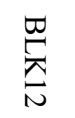 & $\begin{array}{l}\underset{\Xi}{\sigma} \\
\underset{\widetilde{\sigma}}{\omega}\end{array}$ & 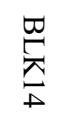 \\
\hline $\begin{array}{l}\text { Implementation of } \\
\text { maintenance works }\end{array}$ & 3.64 & 3.41 & 2.80 & 3.43 & 3.36 & 3.44 & 3.13 & 3.70 & 3.15 & 3.74 & 3.48 & 3.70 & 3.83 & 3.37 \\
\hline
\end{tabular}


Table 4. Delivery feature from end user to the maintenance works for each block

\begin{tabular}{|c|c|c|c|c|c|c|c|c|c|c|c|c|c|c|}
\hline Delivery characteristic & 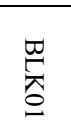 & 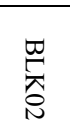 & 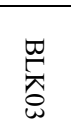 & 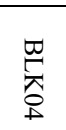 & 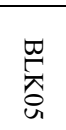 & 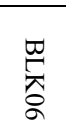 & 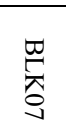 & $\underset{\infty}{\mathbb{\sigma}}$ & 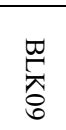 & $\underset{0}{\stackrel{\varpi}{\pi}}$ & $\underset{\stackrel{\varpi}{\overparen{Z}}}{\stackrel{\varpi}{=}}$ & $\frac{\varpi}{\mathbb{\pi}}$ & $\underset{\omega}{\tilde{\sigma}}$ & 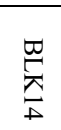 \\
\hline $\begin{array}{l}\text { Response of maintenance } \\
\text { officer/technician. }\end{array}$ & 3.55 & 3.56 & 2.90 & 3.20 & 3.64 & 3.33 & 3.20 & 4.20 & 4.00 & 4.22 & 4.09 & 3.89 & 4.20 & 4.00 \\
\hline $\begin{array}{l}\text { Response of emergencies } \\
\text { defects. }\end{array}$ & 3.45 & 3.44 & 3.00 & 3.20 & 3.64 & 3.44 & 3.30 & 3.50 & 3.36 & 3.56 & 3.36 & 3.89 & 3.70 & 3.50 \\
\hline $\begin{array}{l}\text { Quality of maintenance } \\
\text { works. }\end{array}$ & 3.55 & 3.56 & 3.10 & 3.00 & 3.36 & 3.67 & 3.30 & 4.00 & 3.64 & 4.11 & 3.91 & 4.00 & 4.10 & 3.90 \\
\hline $\begin{array}{l}\text { Communication to } \\
\text { maintenance } \\
\text { officer/technician }\end{array}$ & 3.55 & 3.44 & 2.80 & 3.20 & 3.45 & 3.67 & 3.40 & 3.80 & 3.64 & 3.78 & 3.82 & 3.67 & 4.00 & 3.70 \\
\hline $\begin{array}{l}\text { Overall satisfaction of } \\
\text { maintenance works }\end{array}$ & 3.55 & 3.56 & 3.00 & 3.10 & 3.64 & 3.67 & 3.20 & 3.30 & 3.45 & 3.56 & 3.64 & 3.22 & 3.70 & 3.30 \\
\hline $\begin{array}{l}\text { General condition of this } \\
\text { building operation system. }\end{array}$ & 3.45 & 3.44 & 3.10 & 3.30 & 3.73 & 3.67 & 3.40 & 3.50 & 3.45 & 3.56 & 3.45 & 3.33 & 3.50 & 3.40 \\
\hline $\begin{array}{l}\text { Have you satisfied with } \\
\text { action taken by officer in } \\
\text { charge to manage your } \\
\text { complains? }\end{array}$ & 3.55 & 3.44 & 2.80 & 3.20 & 3.45 & 3.44 & 3.10 & 3.80 & 3.55 & 3.89 & 3.82 & 3.78 & 4.00 & 3.70 \\
\hline $\begin{array}{l}\text { Overall satisfaction of } \\
\text { maintenance works }\end{array}$ & 3.64 & 3.56 & 3.00 & 3.20 & 3.55 & 3.44 & 3.30 & 4.00 & 3.64 & 4.00 & 3.91 & 3.78 & 4.20 & 3.80 \\
\hline
\end{tabular}

Table 5. Overall delivery feature from end user to the maintenance works

\begin{tabular}{|c|c|c|c|c|c|c|c|c|c|c|c|c|c|c|}
\hline \multirow[t]{2}{*}{ Delivery characteristic } & 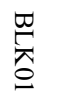 & 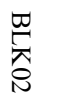 & 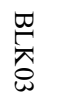 & 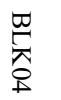 & 苑 & $\frac{\varpi}{\widetilde{\sigma}}$ & 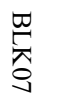 & $\begin{array}{l}\underset{\infty}{\mathbb{\sigma}} \\
\underset{\infty}{\mathbb{S}}\end{array}$ & $\begin{array}{l}\underset{\sigma}{\sigma} \\
\stackrel{\sigma}{\delta}\end{array}$ & $\begin{array}{l}\underset{\sigma}{\sigma} \\
\text { 元 }\end{array}$ & $\begin{array}{l}\underset{\sigma}{\sigma} \\
\underset{\sigma}{\sigma}\end{array}$ & 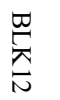 & 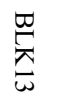 & 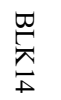 \\
\hline & 3.53 & 3.50 & 2.96 & 3.18 & 3.56 & 3.54 & 3.28 & 3.76 & 3.59 & 3.83 & 3.75 & 3.69 & 3.93 & 3.66 \\
\hline
\end{tabular}

\subsection{Building performance score results for the delivery feature}

Based on the opinions of the end users as given in Table 6, the maintenance management must come up with a strict policy for maintenance works. The score was based on the 4 parameters in the questionnaire. The results from Table 6 also show that generally the performance of the sample blocks was in the 'agree' category (4.00 to 4.99).

This might be due to the intention of the end users to get a delivery system for the effective maintenance of buildings and aspects of effective performance maintenance practices to ensure their environment is safe. The overall opinion in Table 7 together with the results in Table 6 also show that generally the sample blocks 'agree' (4.0 to 4.99) with the performance. 
Table 6. Opinions of end user on maintenance management

\begin{tabular}{|c|c|c|c|c|}
\hline $1.00-1.99$ & $2.00-2.99$ & $3.00-3.99$ & $4.00-4.99$ & $5.00-5.99$ \\
\hline $\begin{array}{c}\text { Very } \\
\text { Dissatisfied }\end{array}$ & Dissatisfied & Average & Satisfied & Very Satisfied \\
\hline
\end{tabular}

\begin{tabular}{|c|c|c|c|c|c|c|c|c|c|c|c|c|c|c|}
\hline $\begin{array}{l}\text { Maintenance management } \\
\text { must produce strictly policy of } \\
\text { maintenance works }\end{array}$ & 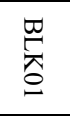 & $\overbrace{\substack{\pi\\
}}^{\infty}$ & 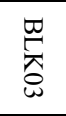 & 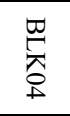 & 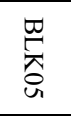 & 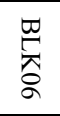 & 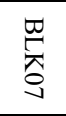 & $\underset{\infty}{\stackrel{\square}{\sigma}}$ & 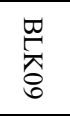 & 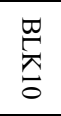 & $\underset{\square}{\stackrel{\varpi}{\Xi}}$ & 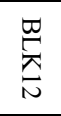 & 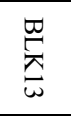 & 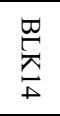 \\
\hline $\begin{array}{l}\text { Planning on maintenance } \\
\text { works that have been carried } \\
\text { out are required to be highly } \\
\text { improved }\end{array}$ & 4.55 & 4.33 & 4.20 & 4.20 & 4.09 & 4.22 & 4.30 & 3.50 & 3.45 & 3.67 & 3.45 & 3.33 & 3.40 & 3.40 \\
\hline
\end{tabular}

\begin{tabular}{|l|l|l|l|l|l|l|l|l|l|l|l|l|l|l|}
\hline $\begin{array}{l}\text { Scheduling on maintenance } \\
\text { work that have been carried } \\
\text { out are required to be highly } \\
\text { improved }\end{array}$ & 4.64 & 4.33 & 4.00 & 4.20 & 4.18 & 4.33 & 4.10 & 3.60 & 3.82 & 4.22 & 4.09 & 4.11 & 4.00 & 4.10 \\
\hline $\begin{array}{l}\text { The work and response of } \\
\text { maintenance officers to solve } \\
\text { the defects on client } \\
\text { complains need improvements }\end{array}$ & 4.55 & 4.11 & 4.10 & 4.20 & 4.18 & 4.22 & 4.20 & 3.80 & 3.55 & 3.67 & 3.45 & 3.33 & 3.40 & 3.40 \\
\hline $\begin{array}{l}\text { Response to emergency } \\
\text { defects need improvements }\end{array}$ & 4.45 & 4.22 & 4.20 & 4.20 & 4.27 & 4.22 & 4.20 & 4.10 & 3.45 & 3.67 & 3.45 & 3.33 & 3.40 & 3.40 \\
\hline
\end{tabular}

Table 7. Overall opinion of end users that maintenance management must produce strict policy of maintenance works for each block

\begin{tabular}{|c|c|c|c|c|c|c|c|c|c|c|c|c|c|c|}
\hline \multirow{2}{*}{$\begin{array}{l}\text { Maintenance management must } \\
\text { produce strictly policy of } \\
\text { maintenance works }\end{array}$} & 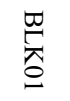 & $\frac{\square}{\tilde{\pi}}$ & $\stackrel{\square}{[}$ & $\underset{\square}{\square}$ & $\underset{\square}{\square}$ & $\stackrel{\square}{\mathscr{T}_{\overparen{R}}}$ & 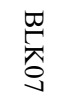 & $\underset{\infty}{\mathbb{\infty}}$ & 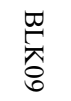 & $\begin{array}{l}\underset{\mathbb{Z}}{\sigma} \\
0 \\
0\end{array}$ & $\begin{array}{l}\underset{\Xi}{\mathbb{Z}} \\
\text { E }\end{array}$ & 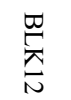 & $\begin{array}{l}\underset{\widetilde{T}}{\sigma} \\
\underset{\omega}{\sigma}\end{array}$ & 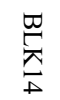 \\
\hline & 4.55 & 4.25 & 4.13 & 4.20 & 4.18 & 4.25 & 4.20 & 3.75 & 3.57 & 3.81 & 3.61 & 3.53 & 3.55 & 3.58 \\
\hline
\end{tabular}

\section{Recommendations}

In order to enhance the effectiveness of maintenance practices, a person must be appointed to be responsible for all aspects of asset maintenance in the building. Bad management may be simply an indication of idleness and waste among maintenance personnel, but there is usually much more to it than that [13]. Therefore, in order to carry out maintenance activities that meet the needs of consumers, the maintenance management should carry out maintenance works smoothly and the person in charge of the maintenance department must be competent in his role and responsibility in handling the complaints received. However, maintenance operation plans and maintenance activities for all aspects of the maintenance practices need to be carried out in a timely manner to reduce the number of recorded complaints. This will give greater confidence to the end users with regard to the implementation of maintenance practices. The maintenance program also needs to be evaluated and reviewed to determine whether the targets have been achieved, and to find out what can be done to solve the remaining problems that have occurred.

\section{Conclusions}

Effectiveness in building maintenance and being able to determine the level of customer satisfaction are some aspects of good building maintenance practices. These approaches may increase 
the potential performance of building maintenance practices by using a strategic performance to achieve the best quality. This study evaluated the integration of the behaviours, perceptions and opinions of building occupants as users of the building. This required a high level of professional skills in meeting the end user needs for a proactive and high quality service. This case study was carried out to evaluate the maintenance services provided and user satisfaction with regard to maintenance management of a government office building in Malaysia. The results of the study can provide some guidelines for key considerations and recommendations for future performance of building maintenance practices in government offices and public buildings. Accordingly, the majority of the performance parameters or aspects of building maintenance practices (building elements, services and environment) are equally in demand for the satisfaction of building occupants.

\section{References}

1. S. Ali, Cost Decision Making In Building Maintenance Practice In Malaysia, Journal of Facilities Management, 7 (4) (2009) 298-306.

2. G.C. Hua, W. Sher, L.S. Pheng, Factors Affecting Effective Communication Between Building Clients And Maintenance Contractors, Corporate Communications: An International Journal, 10 (3) (2005) 240-251.

3. H.H.Y. Lee, D. Scott, Overview of Maintenance Strategy, Acceptable Maintenance Standard and Resources from a Building Maintenance Operation Perspective, Journal of Building Appraisal, 4 (2009) 269-278.

4. J.H.K. Lai, F.W.H. Yik, Monitoring Building Operation And Maintenance Contracts, Facilities, 25 (5/6) (2007) 238-251.

5. M. Bertolini, M. Bevilacqua, M. Braglia, M. Frosolini, an Analytical Method for Maintenance Outsourcing Service Selection, International Journal of Quality \& Reliability Management, 21 (7) (2004) 772-788.

6. M.I Shohet, Key Performance Indicators for Maintenance of Health-Care, Facilities, 21 (1/2) (2003) 5-12.

7. N.E.M. Nik Mat, S. N. Kamaruzzaman, M. Pitt, Assessing the Maintenance Aspect of Facilities Management through a Performance Measurement System: A Malaysian Case Study, The 2nd International Building Control Conference, 20 (2011) 329-338.

8. N.E. Myeda, The Sphere of Performance Measurement in Strategic Facilities Management, Journal of Facilities Management, 10 (3) (2012).

9. N.E. Myeda, S.N. Kamaruzzaman, M. Pitt, "Measuring the performance of office buildings maintenance management in Malaysia", Journal of Facilities Management, 9 (3) (2011) 181199.

10. N. Khalil, A.H. Nawawi, Performance Analysis of Government and Public Buildings via Post Occupancy Evaluation, Asian Social Science, 4 (9) (2008) 103-112.

11. O.A. Lateef, Building maintenance management in Malaysia, Journal of Building Appraisal, 4 (2009) 207-214.

12. O.A. Lateef, M.F. Khamidi, A. Idrus, Building Maintenance Management in A Malaysian University Campuses: A Case Study, Australasian Journal of Construction Economics and Building, 10 (1/2) (2010) 76 - 89.

13. R.M.W. Horner, M.A. El-Haram, A.K. Munns, Building maintenance strategy: a new management approach", Journal of Quality in Maintenance Engineering, 3 (4) (1997) 273-280.

14. S. Wu, K. Neale, M. Williamson, M. Hornby, Research Opportunities In Maintenance Of Office Building Services Systems, Journal of Quality in Maintenance Engineering, 16 (1) (2010) 2333. 